\title{
Psychosocial Impact of Joblessness Due to Covid-19 Pandemic: A Case of Hotel Workers from The Philippines
}

\author{
Mike Haizon M. David, MSHRM1', Alfer S. Sanchez, CHP, MSHTM1, Ilyn M. Mendoza, \\ MSHRM1 \\ ${ }^{1}$ Don Honorio Ventura State University, Philippines
}

\begin{abstract}
The hospitality industry faced extraordinary challenges as opposed to the pandemic that causes the decrease of occupancy rate until $4 \%$ for economy hotels and $15 \%$ for luxury hotels. This condition affects to joblessness of the hotel workers. The study focuses on the psychosocial impact of joblessness due to the covid-19 pandemic on the hotel workers. A qualitative research design was used in this study. Data gathered was from the point of view of the hotel workers of the industries done through interviews online. The implication of the study reveals the challenges brought by this pandemic are mostly loss of revenues leading to employee layoffs. The study reveals that despite the pandemic faced by the industries, the resiliency of Filipinos was evidently seen. Furthermore, the hospitality industry distinguished the impact of Covid-19 on the well-being of hotel workers. Thus, results from this study can be used by companies to develop a more efficient coping mechanism for unforeseen situations like pandemics and any other circumstances unpredicted by humankind.
\end{abstract}

Keywords: psychosocial impact; joblessness; covid-19 pandemic; hotel workers

This is an open access article under the CC-BY-NC license.

\section{INTRODUCTION}

The world's economy was shut down almost overnight due to the Covid-19 pandemic (UNWTO, 2020). The hospitality industry faced extraordinary challenges opposed by the pandemic. It also exhibits as one of the industries with rapid growth, accounting for 8.8 trillion US dollars being outshined only by the sector of manufacturing. But with the recent virus, which was first identified in Wuhan, China December of 2019 and was declared a pandemic dated 12th of Mach 2020, can cause severe acute respiratory syndrome coronavirus 2 (SARS-Cov-2). It has a global economic impact, political and socio-cultural systems. Safety protocols like social distancing, travel restrictions and; community lockdowns were imposed. Hence, it temporarily stopped global travel, tourism and leisure (Sigala, 2020). The virus can spread through human contact. A frightening threat to everyone was the portrait. However, the hospitality and tourism industry was hardly hit. 
Tourism and Sustainable Development Review Journal (TSDR), Vol. 2 (2), 59-70

Psychosocial Impact of Joblessness Due to Covid-19 Pandemic: A Case of Hotel Workers from The Philippines

Mike Haizon M. David, MSHRM, Alfer S. Sanchez, CHP, MSHTM, Ilyn M. Mendoza, MSHRM

The first attempt in order to stop the virus was to shut down operations from airlines to accommodation down to the foodservice industry.

A recent study had foreseen the recovery brought by the pandemic could take until 2023 or later. A similar perspective of hotel companies' prospects are provided by the investors; the underperformance of US lodging real estate investment trusts (REITs) was spotted. Furthermore, many industries, not only the hospitality industry but will also perceive both subtle and significant shifts in the post-pandemic era, of which some are already noticeable today (Krishan et al., 2020).

In the article of McKinsey \& Company, they examined a set of regaining scenarios for US hotels, recovery and return of operations for hotels from economy to luxury segment was included. Health safety protocols of the consumers were their first response; they wanted to feel safe when travelling, check-in and check-out procedures must also be based on less contact with human personnel. Hotels in the US, especially luxury hotels, are closed, which illustrates a major decline in occupancy rates as a result of the pandemic we are facing. For luxury hotels occupancy rate was less than 15\%, and around 4\% for economy hotels in early May was posted.

As discussed by Minene et al. (2020), as COVID-19 was considered a pandemic that shocked the whole world, the safety of everyone was taken into consideration first; protecting its people is what every government focus on. Thus, economic growth was in question, especially for businesses. The impact was really unpredictable; it created damage already. Hence with the current situation the hospitality industry is facing, they remained focused and tried to understand possible solutions to make the industry keep going. The impact on worldwide tourism is huge, from the decisions to shut down hotels, restaurants and to stop tourism in areas that have a high number of people infected by the virus. With these being said, travel agencies, tour operator, investors as a team are doing their best to maintain a good relationship with their stakeholders.

Another factor to consider also is the travellers. Establishments should consider giving promotions. Additional perks, like waiving parking fees or offering discounts on services. Though there is still a risk to travel, and the time that things will get back to normal is still unforeseen, management, however, must have strategic planning with their stakeholders on how will the business face the fact that the pandemic is already here to stay. Travel insurance policies must be reviewed and modified into the current situation until business begins to pick up again (Combs, 2020).

The main objective of this study is to study the psychosocial impact of joblessness due to covid-19 on hotel workers with the following specific objectives:

1. To know the difficulties and challenges they encountered during the pandemic

2. To know Coping mechanisms on the situation, they are into

3. To know the life's realization of hotel workers during the pandemic

\section{LITERATURE REVIEW}

\section{Impact on the Hotel Industry}

As reviewed by Dube and Gandhi (2020), almost all of the industries are trying to stand the impact of the pandemic, one of these is the hotel industry, doing all it takes to adopt the best practices to become more prepared to potentials of not just a second wave but through the worse. The first country to suffer is China that it was reported that hotels in China, as of January and 
Tourism and Sustainable Development Review Journal (TSDR), Vol. 2 (2), 59-70

Psychosocial Impact of Joblessness Due to Covid-19 Pandemic: A Case of Hotel Workers from The Philippines

Mike Haizon M. David, MSHRM, Alfer S. Sanchez, CHP, MSHTM, Ilyn M. Mendoza, MSHRM

February, had sudden occupancy rate declines, down to $14 \%$ as compared to $58 \%$ in the year 2019 . Hotels in China have recovered their strength, with a $47 \%$ occupancy rate at the end of June.

Temporary closure of many hospitality businesses with the implementation of policies to flatten the curve of the Covid-19 pandemic and with limited operation had resulted in the decreased demand for businesses (Bartik et al., 2020). However, gradually restrictions lifted and reopening started to ease, like reducing the seating capacity on dine-in but with strict social distancing guidelines.

According to Gössling et al. (2020), slowly, the hospitality industry is recovering in the hospitality industry from the COVID-19 pandemic. There are changes in the usual operation, and health safety protocols were already included as part of the daily routine to encourage customers' to still continue their support to establishments as well as for the safety of the company's employees.

Base on the findings of Gursoy and Chi (2020), customers will only feel at ease with staying at hotels that are located in areas with few COVID-19 cases. In addition, there are tourists who will only go back to the dining experience once the COVID-19 vaccine becomes available for everyone.

Jiang and Wen (2020) emphasized the need for establishment to strictly follow the healthcare sector. A research agenda was identified, with three dimensions artificial intelligence (AI) and robotics, hygiene and cleanliness and health and health care. In which it recommends moving beyond usual viewpoints on the experiences and outcomes when it comes to hotel safety protocols.

According to Bonfanti et al. (2021), looking into how each hotel manager is practising safe customer experiences is a big deal for guests. There are seven safety measures: hygiene and protection, internal work reorganization, servicescape reorganization, investments in technology and digital innovations, customer wait time reorganization, staff training, and updated communication.

The "new normal" setup is expected in any establishment. In the hotel industry, it is called the "new service design". Everyone is now conscious of safety and sanitation (Awan et al., 2020).

Gössling et al. (2020) stated that integrating and adopting technologies in hospitality operations will be likely integral in the near future with recent development in artificial intelligence (AI) and social service robot technologies. Gursoy et al. (2020) stated in their findings the use of technology would be needed to fight the COVID-19 pandemic. It will help minimize face-to-face interaction. Examples of these are the following: contactless payments, service robots, digital menu, keyless entry to rooms and many more.

\section{Psychosocial Impact}

The COVID-19 outbreak affected all segments of the population, and it is mainly unfavorable to people with the most vulnerable situations. This includes the unfortunate people, senior citizens, and persons with disabilities, the young and indigenous peoples. Homeless people are vulnerable to the virus as well as they don't have shelters to stay safe. And without adequate access to running water, disinfectants like alcohol are very likely to be exposed to the threat of the virus. 
Tourism and Sustainable Development Review Journal (TSDR), Vol. 2 (2), 59-70

Psychosocial Impact of Joblessness Due to Covid-19 Pandemic: A Case of Hotel Workers from The Philippines

Mike Haizon M. David, MSHRM, Alfer S. Sanchez, CHP, MSHTM, Ilyn M. Mendoza, MSHRM

According to a United Nations article, people are suffering, people are dying, and the life of a normal human being is not the same as before the pandemic arrived. The pandemic is hitting not only human lives but also it is an economic and social crisis. It is a pandemic attacking society's lives. It may also increase disparity, segregation, discernment and global unemployment in the long period if not properly given action through policy the social crisis. Universal social protection systems play a role in protecting workers and in reducing the incidence of scarcity. They provide basic income security, thus giving people's hope to manage and overcome shocks.

A study conducted by Wong et al. (2021) stated that the outbreak has led to occupational stressors such as traditional hotel-work stressors, unstable and more demanding hotel-workenvironment stressors, and unethical hotel-labour-practices-borne stressors. Hence, findings on their study showed that organizational commitment and job satisfaction significantly described job performance. The turnover intention was not influenced by those factors. But employees' perceptions changed after the pandemic emerged.

According to Bajrami et al. (2021), test the various effects of COVID-19, which was seen through job insecurity, employees' health complaints that happened during the isolation process, risk-taking behaviour at workstation and changes made in the organization. These had an impact on work-related attitudes and attrition rates of the employees in the hospitality industry.

Hofmann, and Stokburger-Sauer, (2017), explained that work-life balance and job satisfaction determined employees' commitment to an organization. Emotional labor has an effect on employees' commitment that increase retention in the hotel firm.

According to Agarwal (2021), specified that offering guidance when managing people effectively in times of crisis will strongly impact employees' well-being. It incorporates the insights from an HRM framework using a job demands-resources model. Results are very important for policymakers of an organization.

During a crisis, a manager's duty is to empower the employees to stay strong despite the challenges that may change the way employees perceived life. A study was conducted to examine the role of emotion in developing employees' trust in an organization. Findings revealed that how manager reacts and deals with a crisis like COVID-19 pandemic greatly affects the behaviour employees (Guzzo et al., 2021).

\section{RESEARCH METHOD}

\section{Research Design}

This study utilized the qualitative study, primarily the phenomenological method, to describe the experiences of hotel workers during this pandemic. Qualitative research generates words rather than numbers because it aims to understand the aspect of social life (Bricki, 2007).

\section{Participants}

The participant of the study was selected from the DOT accredited hotel. Five hotels volunteered to participate and interview approximately 4-5 employees from every hotel for a total of 23 participants. The interview was conducted online. The interview guide was validated by three experts in the hospitality and tourism industry. Purposive sampling was used as a strategy. Purposive sampling is where respondents are selected or sought after based on pre-selected criteria based on their function as employees of the hotel from managerial level to different 
Tourism and Sustainable Development Review Journal (TSDR), Vol. 2 (2), 59-70

Psychosocial Impact of Joblessness Due to Covid-19 Pandemic: A Case of Hotel Workers from The Philippines

Mike Haizon M. David, MSHRM, Alfer S. Sanchez, CHP, MSHTM, Ilyn M. Mendoza, MSHRM

departments of the hotel such as housekeeping, operations, sales and guest services. The demographic of the sample size being presented in Table 1.

Table1. Sample Details

\begin{tabular}{lllll}
\hline S. No. & Position & Gender & Hotel & Location \\
\hline 1 & Head, Cost Control & Female & Hotel1 & Clark \\
2 & Receptionist & Female & Hotel 1 & Clark \\
3 & Waiter & Male & Hotel 1 & Clark \\
4 & Chef & Male & Hotel 1 & Clark \\
5 & Bartender & Male & Hotel 1 & Clark \\
6 & Area supervisor & Female & Hotel 2 & Clark \\
7 & F\&B Waiter & Male & Hotel 2 & Clark \\
8 & Receptionist & Female & Hotel 2 & Clark \\
9 & Finance staff & Male & Hotel 2 & Clark \\
10 & FO Head & Female & Hotel 3 & Clark \\
11 & Banquet Manager & Female & Hotel 3 & Clark \\
12 & Receptionist & Male & Hotel 3 & Clark \\
13 & Waiter & Male & Hotel 3 & Clark \\
14 & Bell boy & Male & Hotel 3 & Clark \\
15 & Chef & Male & Hotel 4 & Clark \\
16 & Steward & Male & Hotel 4 & Clark \\
17 & Bartender & Male & Hotel 4 & Clark \\
18 & Receptionist & Female & Hotel 4 & Clark \\
19 & Waitress & Female & Hotel 4 & Clark \\
20 & HR head & Male & Hotel 5 & Clark \\
21 & Housekeeper & Male & Hotel 5 & Clark \\
22 & Receptionist & Female & Hotel 5 & Clark \\
23 & Waiter & Male & Hotel 5 & Clark \\
\hline & & & & \\
\hline
\end{tabular}

\section{Data-Gathering}

Data gathering procedures are as follows: rapport building, interview proper, transcription of the interviews, and data sources verification. A letter was sent to the participants in order to inquire about their availability and to provide them with the necessary information, and obtain their consent to participate. An orientation was conducted before the actual interview to establish rapport with the participants. Data collected during the interview was transcribed and were given back to the participants for verification. The process of analyzing data involves four major steps: the search for themes in the first case, the connection of the themes, the continuation of the analysis with other cases, and lastly, the writing up. The first step requires a rereading of the transcript in order to be familiar with the account and the possibility for new insights to emerge. The second one involves the connection of the themes because some themes will cluster together while other themes may emerge as superordinate concepts. The third step is the continuation of the analysis with other cases, which may open new themes or previous themes may re-emerge. Then, a final list of themes was constructed, deciding which themes to focus upon. The last step is concerned with 
Tourism and Sustainable Development Review Journal (TSDR), Vol. 2 (2), 59-70

Psychosocial Impact of Joblessness Due to Covid-19 Pandemic: A Case of Hotel Workers from The Philippines

Mike Haizon M. David, MSHRM, Alfer S. Sanchez, CHP, MSHTM, Ilyn M. Mendoza, MSHRM

translating the themes into a narrative account. Here, the analysis becomes expansive again, as the themes are explained, illustrated and nuanced (Smith \& Osborn, 2007).

\section{Data Analysis}

The qualitative data from interviews were interpreted using the thematic analysis that familiarizing yourself with the date, generating initial codes, searching for themes, reviewing themes, defining and naming themes and producing the report. The study conducted pilot testing three participants to confirm the interview that they could understand the questions properly. The interviews last for 10 to 30 minutes.

\section{FINDINGS AND DISCUSSION}

The study identified factors on psychosocial impact of hotel workers due to covid-19 pandemic with the classified themes, difficulties and challenges, coping mechanism and life' realization. Overall, 15 participants experienced cancel booking, no employee layoff, flexible working arrangement, company provide a free meal, allowance, transportation and hazard pays, community quarantine hotel, must have a contingency plan, value for time, value for money, job resilience, and things will back to normal.

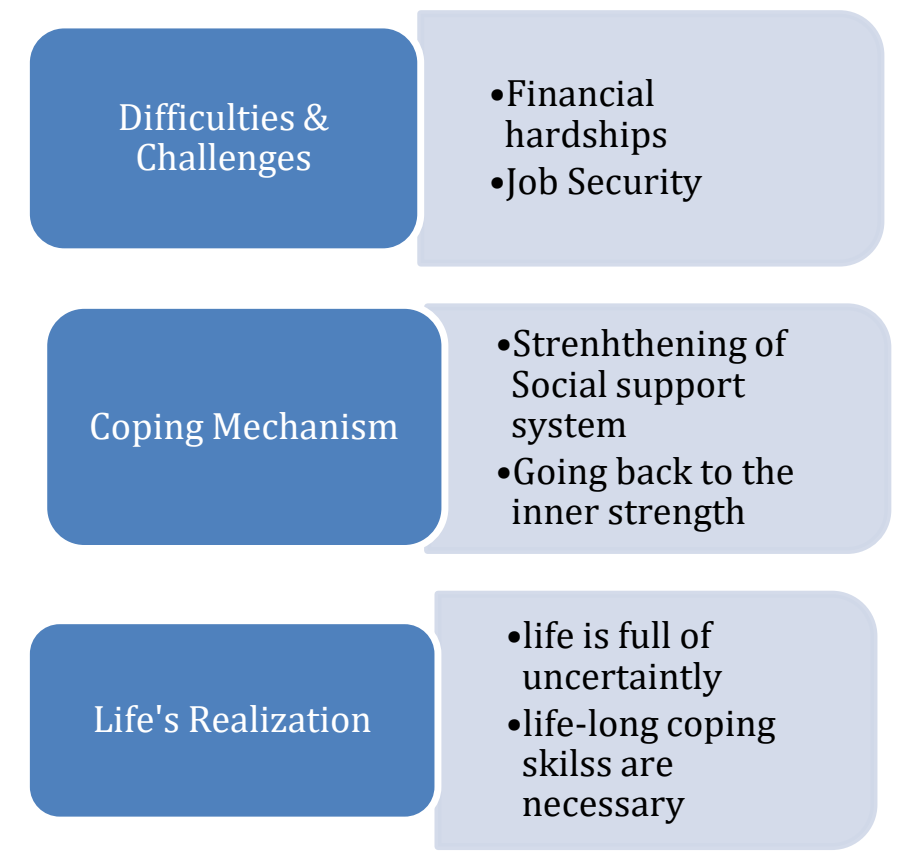

Figure 1. Themes and Subthemes

\section{Difficulties \& Challenges}

Financial hardships

All the hotels encountered during the pandemic were the loss of hotel booking, followed by the loss of sales and loss of revenue. Participants narrated how their operation was going after lockdown. 
"When we resumed after our operations after lockdown, there were huge changes, there were bookings that were cancelled. We are required to be a quarantine hotel. There were so many cancellations and we also have negative guest reviews, because other guests do not understand why we have to cancel their bookings despite the lifted quarantines. But we still received bookings from DOH and OWWA."

Participants said that although operations were back to normal, they are not still hitting their target sales because of under booking which

"We have under bookings. Only 30\% of the normal sales were back."

The same goes for participants, wherein she emphasized the difference in their occupancy rates before and during the pandemic.

"We have cancelled bookings. Before pandemic the bookings was $90 \%$ then down to 10 to $20 \%$. We have very low occupancy rate which means low revenue."

Job insecurity

Management support during this time of pandemic is very crucial. Three hotels were able to manage the challenges brought by the pandemic through their coping mechanisms. The participants who were not fired were insured about their jobs. Employees reported anxious about job loss. Participants discussed how supported their company was.

"We are very thankful for our company; we are one of the hotels in Clark that did not experienced layoff, despite of lockdown and quarantines. Our agencies did not abandon us, be it agency or direct, all were provided assistance and allowance. We have some turnover also but not connected with the pandemic."

According to participants, layoff was not an option for some hotels during this time of the pandemic. The temporary closure was necessary during the lockdown, but they provided other solutions like flexible working arrangements and furlough.

"During lockdown, we are temporarily closed but we did not consider employee layoff, we consider flexible working arrangement instead. We reduced the number of working days employees, instead of losing their job."

To secure the company, two hotels-imposed employee lay off and provide flexible working loads in order to sustain the operation during the lockdown; layoff was considered according to participants.

"The management needs to sacrifice some of their employees because it is necessary for this situation. We implemented also a flexible working arrangement and our employees were stay-in at the hotel for safety purposes. They were also provided free meals, 3 times a day and midnight snacks was included and hazard pay for all employees were given." 
Tourism and Sustainable Development Review Journal (TSDR), Vol. 2 (2), 59-70

Psychosocial Impact of Joblessness Due to Covid-19 Pandemic: A Case of Hotel Workers from The Philippines

Mike Haizon M. David, MSHRM, Alfer S. Sanchez, CHP, MSHTM, Ilyn M. Mendoza, MSHRM

Fifteen participants experience flexible working arrangements. HIR3 added that employees stay at the hotel because of lockdown, adjustment on working schedules and shortage of deliveries was experienced.

"During the lockdown, there were 100 employees who were stay-in at the hotel. Because during that period, there were businesses that are still operational, what they did was to check-in at several hotels. So what we did was to select 100 employees to continue the operation to serve and provide their needs. However, deliveries and orders to supply the stay-in guest are a bit hard because of the lockdown. Working schedules of employees was adjusted also to 12-14 working hours to sustain the operation."

\section{Coping Mechanism}

Strengthening of Social Support System

Fifteen participants had support from the company by providing them with a free meal, allowance, transportation, and hazard pays. Participants stated that

"Although we experience layoff our company provide us free meal three times a day and midnight snacks included, free shuttle service, allowance and hazard pay for all employees "

Going back to the inner strength

All Hotels accredited by Tourism and Health Agencies became quarantine hotels, passengers arriving in the Philippines while waiting for the release of results of their swab test are required to hold a confirmed booking. participants being a quarantined hotel proudly stated that their level of commitment to service did not change.

"We are one of the quarantine hotels, but we still received good comments regarding our service despite the fact they are on quarantine."

Participants also mentioned they did their participation to act as a quarantined hotel.

"Our hotel was designated as one of the quarantine facilities."

As for participants, their hotel gave discounts for everyone. But she indicated it's their strategy to help the community and the company as well.

"We gave 50\% discount for everyone but it's a win-win situation for everyone."

\section{Life's Realization}

Life is full of uncertainly

All hotels are susceptible to some amount of risk. Contingency planning can be effective in alleviating these risks. Participants realized the value of having a contingency plan for every situation.

"Everything must be planned. If not planned, we must have contingency plan, if ever there are calamities like this. Not just in terms of figures, revenues, but in terms of services also that we need to provide our guests."

Money was said to be very important during this time of the pandemic. Participants stated their realization about money. 
Tourism and Sustainable Development Review Journal (TSDR), Vol. 2 (2), 59-70

Psychosocial Impact of Joblessness Due to Covid-19 Pandemic: A Case of Hotel Workers from The Philippines

Mike Haizon M. David, MSHRM, Alfer S. Sanchez, CHP, MSHTM, Ilyn M. Mendoza, MSHRM

"I realized the value of money, same thing with employees. We must not take for granted the value of money, we must learn to save."

Participants added,

"We cannot do anything about what happened, but we really realized we need to save money for instances like this."

Life-long coping skills are necessary.

Words of encouragement are powerful to boost the morale of people. It's a powerful weapon to keep on fighting with every challenge life has to offer. Participants encourage everyone not to give up, they all believed that this pandemic is about to end.

Participants: "We are looking for more, for the better future of the industry; it may be a little down this time, but definitely we are looking to a lot of improvements and developments. Everyone is creating and doing their simple ways to make it better and to back to the normal thing."

Participants: "Just take a look on the brighter side. As long as it is your dream, pursue it. As we can see, things are getting back to normal little by little. Things will be okay in God's perfect time.

Participants: "We may be struggling for now, but don't give up. Things will get better."

\section{Discussion}

The first objective was difficulties and challenges, as the restriction and lockdown implemented by the government, all the operations in all industries stopped. Among the biggest industry affected by the COVID-19 pandemic was the hospitality industry, which situation resulted in a decrease in their revenue. With these factors hotel, industry tremendously experienced a downfall in its operations and a decline in sales.

The study reveals that when the consumer feels unsafe with the product or service being offered, it turns out that there will be a decrease in one's intention to purchase. According to Li et al. (2021), due to the COVID-19 pandemic, consumer purchase decision was affected. Safety comes first before purchasing services of the hospitality industry. Customer reviews were a big factor in knowing if a place is safe to visit or not. Caligiuri et al. (2020) discussed how pandemic affects the flow of businesses from cross-border problems as the result of imposing travel bans. This affected employees who need to travel before reaching their workplace. It resulted in remote working. Thus, this helps employees to gain more opportunities, trainings, and support from companies. On the contrary, job security, one of the corporate responsibilities of the company, is to save the company from closure. In doing so, they need to do interventions like decreasing working hours or a day or decreasing employees. The study reveals that although there is decreased in sales, hospitality businesses manage to lessen layoffs and implement flexible working arrangements. Hotel workers have a job this time of pandemic crisis; they feel secure to survive the crisis. As stated in the study of Filimonau et al. (2020), organizational response to COVID-19 increases managers' organizational commitment and affects perceived job security. In order to save the company and its employees, some hotels experienced layoffs and implemented flexible working arrangements.

The second objective on coping mechanism was revealed on the social support system that hotel company must be considered the welfare of their employees during the crisis in providing a 
Tourism and Sustainable Development Review Journal (TSDR), Vol. 2 (2), 59-70

Psychosocial Impact of Joblessness Due to Covid-19 Pandemic: A Case of Hotel Workers from The Philippines

Mike Haizon M. David, MSHRM, Alfer S. Sanchez, CHP, MSHTM, Ilyn M. Mendoza, MSHRM

free meal, allowance, transportations and hazard pay. Guzzo et al. (2021) stated that during a crisis such COVID -19 pandemic influence employees' organizational trust and observed the role that emotions play in developing organizational trust. What influences organizational trust is the feeling of gratefulness and fear. Understanding organizational trust during a crisis is essential. While on going back to the inner strength, in the initiatives of the government to convert or use the hotel as quarantine facilities which hotel can gain revenue. Salem et al. (2021) specified that the government, together with chain-managed five-star hotels, engaged in a number of initiatives focusing on financial policies, training, marketing, possible domestic tourism, flexibility to booking and cancellation policies, and others that contribute to crisis management.

Third, on the life's realization, attest the resiliency of the Filipinos that whatever trial or crisis encountered, they still have strong faith to overcome the situation. Aguiar-Quintana et al. (2021) examined if job insecurity on hotel employees' causes anxiety and depression and whether these psychological strains could contribute to employees' self-rated task performance during the pandemic. Results showed that employees' self-rated task performance was not affected by their job insecurity or by their anxiety and depression. Furthermore, employees' resilience has a moderating effect, as it lessens the negative effects of the said variables.

\section{CONCLUSION}

Participants experienced changing working conditions but also positive factors such as increased team unity and greater reflection on what matters in hotel workers life. It highlights the key difficulties experienced by the hotel workers during the COVID-19 pandemic. The findings stipulate initiatives from the government to support and give subsidies to the hospitality business to avoid lack of revenue, layoffs and closure of business. In this aspect, challenges that employee encounter is vital as to be addressed for the improvement of the operations. Implication on the coping mechanism as support to employees should highlight people-oriented-leader that manifest success by building a lasting relationship with employees. Developing organizational trust and strengthening crisis management are the best strategies of hospitality business as a coping mechanism in a time crisis. On life's realization, businesses should consider employees' well-being to provide space intervention such as activities. These activities may secure hotel workers during emergency circumstances, the edifice of resilience and positive surviving outside of pandemic situations and the undertaking of problems such as job insecurity will possible be addressed as coping capacity in future epidemic situations. Employee well-being and employee resilience are the strongest factors to consider in facing a crisis. This study can be used by companies as a reference on how to face or cope up with a crisis, and future researchers can also consider the challenges experienced by the participants during the pandemic.

\section{REFERENCES}

Agarwal, P. (2021). Shattered but smiling: Human resource management and the well-being of hotel employees during COVID-19. International Journal of Hospitality Management, 93, 102765. https://doi.org/10.1016/j.ijhm.2020.102765

Aguiar-Quintana, T., Nguyen, H., Araujo-Cabrera, Y., \& Sanabria-Díaz, J. M. (2021). Do job insecurity, anxiety and depression caused by the COVID-19 pandemic influence hotel employees' 
Tourism and Sustainable Development Review Journal (TSDR), Vol. 2 (2), 59-70

Psychosocial Impact of Joblessness Due to Covid-19 Pandemic: A Case of Hotel Workers from The Philippines

Mike Haizon M. David, MSHRM, Alfer S. Sanchez, CHP, MSHTM, Ilyn M. Mendoza, MSHRM

self-rated task performance? The moderating role of employee resilience. International Journal of Hospitality Management, 94, 102868.https://doi.org/10.1016/j.ijhm.2021.102868

Awan, M.I., Shamim, A. and Ahn, J. (2020), "Implementing 'cleanliness is half of faith' in redesigning tourists, experiences and salvaging the hotel industry in Malaysia during COVID-19 pandemic", Journal of Islamic Marketing, Vol. ahead-of-print No. ahead-of-print. https://doi.org/10.1108/JIMA-08-2020-0229

Bajrami, D. D., Terzić, A., Petrović, M. D., Radovanović, M., Tretiakova, T. N., \& Hadoud, A. (2021). Will we have the same employees in hospitality after all? The impact of COVID-19 on employees' work attitudes and turnover intentions. International Journal of Hospitality Management, 94, 102754. https://doi.org/10.1016/j.ijhm.2020.102754

Bartik, A. W., Bertrand, M., Cullen, Z. B., Glaeser, E. L., Luca, M., \& Stanton, C. T. (2020, April). How are small businesses adjusting to COVID-19? Early evidence from a survey (No. w26989). National Bureau of Economic Research. https://www.nber.org/papers/w26989

Bonfanti, A., Vigolo, V., \& Yfantidou, G. (2021). The impact of the Covid-19 pandemic on customer experience design: The hotel managers' perspective. International Journal of Hospitality Management, 94, 102871.https://doi.org/10.1016/j.ijhm.2021.102871

Bricki N. (2007). A Guide to Using Qualitative Research Methodology. https://fieldresearch.msf.org/handle/10144/84230

Caligiuri, P., De Cieri, H., Minbaeva, D., Verbeke, A., \& Zimmermann, A. (2020). International HRM insights for navigating the COVID-19 pandemic: Implications for future research and practice.https://doi.org/10.1057/s41267-020-00335-9

Combs L. (2020, October 30). COVID-19 Impact on the Hospitality Industry. https://www.withum.com/resources/covid-19-coronavirus-impact-on-the-hospitality-industry/.

Dube L. (2020, July 31). Providing High-Touch Through High-Tech: Resilience In Hospitality Through Human, Technology And System Convergence. https://www.hospitalitynet.org/opinion/4099955.html

Filimonau, V., Derqui, B., \& Matute, J. (2020). The COVID-19 pandemic and organizational commitment of senior hotel managers. International Journal of Hospitality Management, 91, 102659.https://doi.org/10.1016/j.ijhm.2020.102659

Gössling, S. , Scott, D. , \& Hall, C. M. (2020). Pandemics, tourism and global change: A rapid assessment of COVID-19. Journal of Sustainable Tourism , 1-20. https://doi.org/10.1080/09669582.2020.1758708

Gursoy, D., \& Chi, C. G. (2020). Effects of COVID-19 pandemic on hospitality industry: review of the current situations and a research agenda. https://doi.org/10.1080/19368623.2020.1788231

Gursoy, D. , Chi, C. G. , \& Chi, O. H. (2020, May 30). COVID-19 Study 2 Report: Restaurant and Hotel Industry: Restaurant and hotel customers' sentiment analysis. Would they come back? If they would, WHEN? (Report No. 2), Carson College of Business, Washington State University. http://www.htmacademy.com/covid-19-research-for-hospitality-industry/covid-19-study-2report-for-the-restaurant-and-hotel-industry/ 
Tourism and Sustainable Development Review Journal (TSDR), Vol. 2 (2), 59-70

Psychosocial Impact of Joblessness Due to Covid-19 Pandemic: A Case of Hotel Workers from The Philippines

Mike Haizon M. David, MSHRM, Alfer S. Sanchez, CHP, MSHTM, Ilyn M. Mendoza, MSHRM

Guzzo, R. F., Wang, X., Madera, J. M., \& Abbott, J. (2021). Organizational trust in times of COVID-19: Hospitality employees' affective responses to managers' communication. International Journal of Hospitality Management, 93, 102778. https://doi.org/10.1016/j.ijhm.2020.102778

Hofmann, V., \& Stokburger-Sauer, N. E. (2017). The impact of emotional labor on employees' work-life balance perception and commitment: A study in the hospitality industry. International Journal of Hospitality Management, 65, 47-58.https://doi.org/10.1016/j.ijhm.2017.06.003

Jiang, Y. and Wen, J. (2020), "Effects of COVID-19 on hotel marketing and management: a perspective article", International Journal of Contemporary Hospitality Management, Vol. 32 No. 8, pp. 2563-2573. https://doi.org/10.1108/IJCHM-03-2020-0237

Krishnan et al. (2020, June 10). Hospitality and COVID-19: How long until 'no vacancy' for US hotels?. https://www.mckinsey.com/industries/travel-logistics-and-transportinfrastructure/our-insights/hospitality-and-covid-19-how-long-until-no-vacancy-for-us-hotels\#

Li, Y., Yao, J., \& Chen, J. (2021). The negative effect of scarcity cues on consumer purchase decisions in the hospitality industry during the COVID-19 pandemic. International Journal of Hospitality Management, 94, 102815. https://doi.org/10.1016/j.ijhm.2020.102815

Minene, Majinke and Haners (2020). Hospitality taking pro-active financial steps to mitigate impact.https://www2.deloitte.com/nl/nl/pages/consumer/articles/impact-of-covid-19-on-thehospitality-industry.html.

Salem, I. E., Elkhwesky, Z., \& Ramkissoon, H. (2021). A content analysis for government's and hotels' response to COVID-19 pandemic in Egypt. Tourism and Hospitality Research, 14673584211002614.https://doi.org/10.1177\%2F14673584211002614

Sigala M. (2020). Tourism and COVID-19: Impacts and implications for advancing and resetting industry and research. https://doi.org/10.1016/j.jbusres.2020.06.015

Smith, J. A., \& Osborn, M. (2007, September 26). Interpretative phenomenological analysis. In J. A. Smith (Ed.), Qualitative psychology: a practical guide to research methods (pp. 53-81). London: Sage. research.sites.olt.ubc.ca/files/2012/03/IPA_Smith_Osborne21632.pdf

http://med-fom-familymed-

United Nations (2020). Everyone Included: Social Impact of COVID-19. https://www.un.org/development/desa/dspd/everyone-included-covid-19.html

UNWTO . (2020). UNWTO world tourism barometer (Vol. 18, Issue 2, May 2020).

Wong, A. K. F., Kim, S. S., Kim, J., \& Han, H. (2021). How the COVID-19 pandemic affected hotel employee stress: Employee perceptions of occupational stressors and their consequences. International Journal of Hospitality Management, 93, 102798. https://doi.org/10.1016/j.ijhm.2020.102798 